\title{
The Role of Pumilio RNA Binding Protein in Plants
}

\author{
Sung Un Huh
}

check for

updates

Citation: Huh, S.U. The Role of Pumilio RNA Binding Protein in Plants. Biomolecules 2021, 11, 1851. https://doi.org/10.3390/ biom 11121851

Academic Editor: Vladimir N. Uversky

Received: 13 November 2021 Accepted: 7 December 2021 Published: 9 December 2021

Publisher's Note: MDPI stays neutral with regard to jurisdictional claims in published maps and institutional affiliations.

Copyright: (C) 2021 by the author. Licensee MDPI, Basel, Switzerland. This article is an open access article distributed under the terms and conditions of the Creative Commons Attribution (CC BY) license (https:/ / creativecommons.org/licenses/by/ $4.0 /)$.
Department of Biology, Kunsan National University, Gunsan 54150, Korea; sungun@kunsan.ac.kr; Tel.: +82-63-469-4587; Fax: +82-63-469-7421

\begin{abstract}
Eukaryotic organisms have a posttranscriptional/translational regulation system for the control of translational efficiency. RNA binding proteins (RBPs) have been known to control target genes. One type of protein, Pumilio (Pum)/Puf family RNA binding proteins, show a specific binding of $3^{\prime}$ untranslational region ( $3^{\prime}$ UTR) of target mRNA and function as a posttranscriptional/translational regulator in eukaryotic cells. Plant Pum protein is involved in development and biotic/abiotic stresses. Interestingly, Arabidopsis Pum can control target genes in a sequence-specific manner and rRNA processing in a sequence-nonspecific manner. As shown in in silico Pum gene expression analysis, Arabidopsis and rice Pum genes are responsive to biotic/abiotic stresses. Plant Pum can commonly contribute to host gene regulation at the posttranscriptional/translational step, as can mammalian Pum. However, the function of plant Pum proteins is not yet fully known. In this review, we briefly summarize the function of plant Pum in defense, development, and environmental responses via recent research and bioinformatics data.
\end{abstract}

Keywords: RNA binding protein; Pumilio; translational modification; RNA biomolecules

\section{Evolutionally Conserved Pumilio RNA Binding Proteins}

Sequence-specific RNA binding proteins (RBPs) could play important roles in transcriptional/translational regulation via direct binding to specific cis-acting elements of target mRNA, usually located in 3'-untranslated regions (UTRs) [1-3]. Furthermore, most known RBPs might repress translation by binding to a $3^{\prime}$ UTR because they contain regulatory elements for mRNA stability, localization and translation [4-6]. Other RBPs also can affect translation regulation in $5^{\prime}$ UTRs because of their ribosomal protein binding site [7]. Sometimes, RBPs work with miRNAs to control target mRNAs and to mediate the cell-to-cell trafficking of RNAi signals [8,9].

Pumilio (Pum)/Puf family RNA binding proteins are highly conserved in various organisms $[10,11]$. Interestingly, plant Pum genes have more highly diverse members than mammalian Pum genes. For instance, human and mouse genes have the two homologs [11-13]. Caenorhabditis elegans and Saccharomyces cerevisiae have eleven and six homologs, respectively [14,15]. Trypanosoma cruzi and Plasmodium falciparum have ten and two homologs, respectively $[16,17]$. Drosophila melanogaster encodes two functional protein isoforms. These Pums are implicated in diverse physiological processes, specifically development [18]. When affinity-tagged-Pum is expressed in the ovaries of D. melanogastor, putative Pum-associated mRNAs were recovered in over 1000 genes which are believed to contain Pumilio RNA-binding motifs at the $3^{\prime}$ UTRs [19]. It might be possible that just one Pum could control about $10 \%$ of all genes in D. melanogaster. Similarly, yeast Pum proteins have multiple RNA targets [14]. Thus, it is important to understand translational regulations via Pum proteins because of their specific capacity to bind to cis-elements in the $3^{\prime}$ UTR of target mRNA. In the present study, plant Pums showed that the Arabidopsis, rice, soybean, apple, and corn genomes contained the largest number of putative Pum homolog proteins, about 20 homologous members, via analysis with Plaza 2.5, which is a comparative genomics analysis tool (Figure 1A) [20]. On the contrary, green algae such as Ostreococcus tauri, Chlamydomonas reinhardtii and Volvox carteri have small numbers of 
putative Pum genes in their genomes (Figure 1A). It is reasonable that plants have larger genomes than other eukaryotic organisms. In a plant's evolution, it might have developed mechanisms to cope with abiotic and biotic stresses imposed by the adverse environment and pathogen infections. Thus, a plant might need to have a complicated regulation system against adverse conditions. The diversity of plant Pum genes could contribute to the post-transcriptional/translational regulation of many genes such as identified mammalian Pums.

A

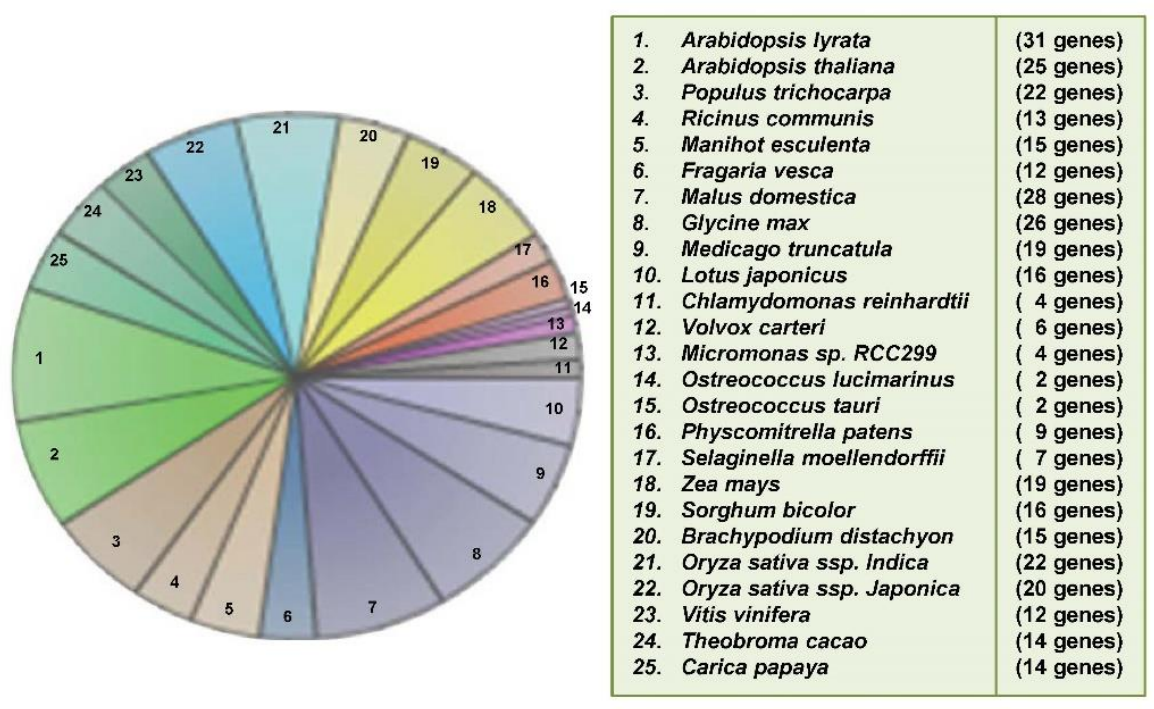

B

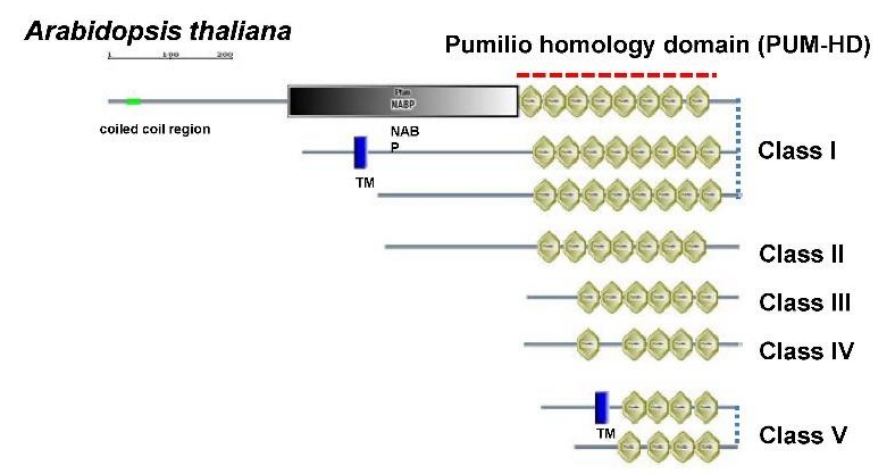

Saccharomyces cerevisiae

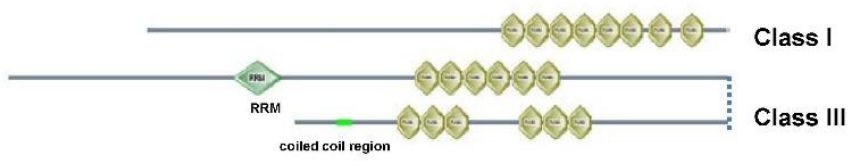

Trypanosoma brucei

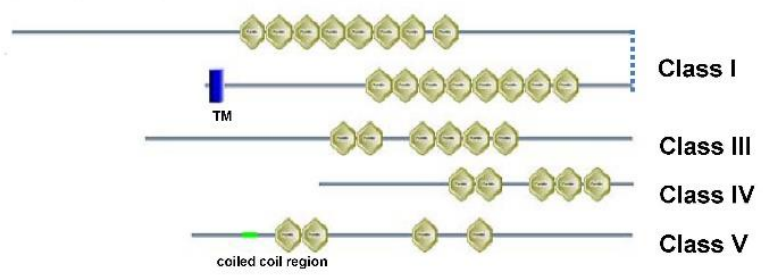

Figure 1. Analysis of putative Pum in green plant species. (A) Pum-HD is used in the analysis of putative plant Pum genes. The functional clusters are associated with InterPro domain (IPR001313) via Plaza 2.5, which is a comparative genomics analysis tool (http:/ / bioinformatics.psb.ugent.be/plaza/ 
accessed on 13 November 2021). (B) Classified via alpha helical repeats of Pum-HD. Arabidopsis thaliana, Saccharomyces cerevisiae and Trypanosoma brucei Pum proteins are analyzed via SMART tool (http: / / smart.embl-heidelberg.de/ accessed on 13 November 2021). The Pum class is divided into the numbers of alpha helical repeats of Pum-HD. Class I contains eight alpha helical repeats of Pum-HD. Class II contains seven alpha helical repeats of Pum-HD. Class III contains six alpha helical repeats of Pum-HD. Class IV contains five alpha helical repeats of Pum-HD. ClassV contains four alpha helical repeats of Pim-HD. Other domains are indicated in the box.

\section{RNA-Binding Specificity of Pumilio-Homology Domain}

To date Pum proteins have been described to be defined by a highly conserved Pumilio RNA-binding domain in the C-terminal region. Pum classes were sorted by the numbers of the alpha helical repeats of the Pumilio-homology domain (Pum-HD) via SMART tool and were mainly represented as the canonical and non-canonical Pum-HD (Figure 1B) [21]. Pum-HD is necessary and sufficient for sequence-specific RNA binding [22-24]. Basically, the eight alpha helical repeats of Pum-HD could confer recognition and binding affinity to a Pumilio RNA binding motif of the target RNA [25]. Engineered and customized Pum-HD protein could help control specific target regulation [26-30]. In yeast, PUF3, 4 and 5 have putative targets of about 200 genes, and the target mRNA contains the conserved 'UGUX ${ }_{3-5} \mathrm{UA}^{\prime}$ motifs [14,31]. Arabidopsis Pum, APUM5 has eight alpha helical repeats and confers resistance to Cucumber mosaic virus (CMV) via direct binding to CMV $3^{\prime}$ UTR contained in a putative Pumilio RNA-binding motif. A recombinant GST-APUM5-PumHD protein has binding activity with regard to the Nanos regulator element sequence (NRE), which is recognized by Drosophila Pum [32,33]. APUM1 to 6 members also exhibit binding activity with regard to the NRE in yeast three hybrids [34]. Yeast PUF2 has one RNA-recognition motif (RRM) and six alpha helical repeats of Pum-HD (Figure 1B). Yeast PUF1 and PUF2 might posttranscriptionally regulate the cell wall integrity pathway by controlling the Zeo1 gene in $\mathrm{CaCl}_{2}$ stress [35]. However, ASH1 is the target of yeast PUF6, which contains six alpha helical repeats of Pum-HD [36]. This means that fewer alpha helical repeats of Pum-HD can confer the binding activity of target RNA, but it is hard to identify the regulation of target RNA.

The function of APUM23, which contains seven alpha helical repeats of Pum-HD, is involved in pre-rRNA processing in the nucleolus. The apum 23 mutant exhibits a similar developmental phenotype to nucleolin and ribosomal protein mutants [37]. Similarly, $S$. cerevisiae PUF4, which contains eight alpha helical repeats of Pum-HD, binds to mRNAs encoding nucleolar ribosomal subunits [14,25]. This indicates that plant Pum protein could possibly contribute to the regulation of pre-RNA processing via target binding of nucleolar ribosomal RNA-processing factors.

Some plant Pum proteins contain another functional domain. For example, the nucleicacid binding protein (NABP) domain has nucleic acid binding activity [38]. It is believed to bind to RNA with a broad specificity and is especially found in several plant Pum-HDs (Figure 1B). The NABP domain is specific to the plant Pum family, and its function is not clear. RNA RRM is one of the most abundant RBDs in eukaryotic cells and confers a variety of RNA bindings [39]. Several plant Pums contain an RRM. It might function in RNA recognition as a helper protein (Figure 1B) [6]. Additionally, plant Pums have a transmembrane domain which has a single transmembrane alpha helix and is specifically localized to membrane compartments (Figure 1B) [40].

\section{Protein-Protein Interaction in Plant Pum}

Pum-HD has a dual function. The inner surface of Pum-HD binds to the conserved 'UGUX ${ }_{3-5} \mathrm{UA}^{\prime}$ ' motif in the $3^{\prime}$ UTR regions of the target gene. Interestingly, the outer surface of Pum-HD also permits protein-protein interactions with diverse proteins [6,41]. The yeast Pum protein, PUF5p, binds to and represses $H O$ mRNA, which encodes a DNA endonuclease via binding to the Pumilio-RNA binding motif. Pop2p, which encodes a component of the Ccr4p-Pop2p-Not deadenylase complex, is required for PUF5p-mediated 
HO mRNA decay [42]. It affects both mRNA stability and translational efficiency [43,44]. Thus, Pums do not work alone to repress the target mRNA. Furthermore, yeast PUF5p and Pop2p interaction is evolutionally conserved in C. elegans PUF8 and H. sapiens (PUM1) [42]. Arabidopsis Pum, APUM5, also interacts with plant Ccr4 homologues [45]. Sometimes, yeast PUF5p does not require Ccr4-Pop2 deadenylase when PUF5p responds to DNA replication stress [46]. Thus, plant Pum function could be associated with deadenylasedependent and -independent pathways via formation, as with Ccr4-Pop2-NOT mRNA deadenylase complexes.

Human PUM2 can make a complex with Argonaute (Ago) miRNA-binding protein, and then, the PUM2-Ago heterodimer is associated with the core translational elongation factor (eEF1A). This complex inhibits eEF1A GTPase activity and translational elongation [47]. These results imply that plant Pum could be associated with the Ago-eEF1A protein complex.

\section{Dynamic Subcellular Localization of Plant Pum}

To regulate diverse target genes, Pum might have to locate in other organelles or some specific regions at the subcellular level. Plant Pum has various subcellular localization patterns $[37,40,48]$. For example, APUM9 has a transmembrane domain in the $\mathrm{N}$-terminal region and locates the cytoplasmic-punctuated structure region [48]. APUM5 has a putative transmembrane domain in the $\mathrm{N}$-terminal region and localizes to cytoplasmic-punctuated structures and vacuolar structures in tobacco epidermal cells [40]. Recently, regarding APUM6 subcellular localization, it has been clearly observed that APUM6 localizes on the surface of the endoplasmic reticulum (ER) but still shows dynamic localization patterns [10]. APUM6 might have diverse functions in different organelles. APUM23 and APUM24 have a putative nuclear localization signal in the C-terminal region and normally localize to nucleolar-like structures in planta [37,48,49]. Interestingly, ChPUM2 and ChPUM3 from Chara corallina also show similar nucleolar localization [49].

\section{The Role of Pum in Plant Development}

Pum proteins play important roles during development, differentiation and cell cycle regulation in various organisms [33,50]. APUM1 to APUM6 are specifically associated with shoot stem cell maintenance genes such as WUSCHEL (WUS) and CLAVATA1 (CLV1) [34,51,52]. Like the mammalian system, human PUM2 is expressed in embryonic stem cells and could affect germ cell development [53]. Mammalian PUM1 and PUM2 regulate cell cycle inhibitor Cdkn1b via translational control [54]. C. elegans Pum, PUF8, might function as a repressor of the stem cell proliferative fate via control of GLP-1/Notch signaling in germline cells [55]. Likewise, plant Pum could affect a variety of development stages. Gene expressions of APUM23 and APUM24 were shown to be continuously expressed in all the developmental stages and were enhanced at the seed stage (Figure 2A). APUM23 affects pre-ribosomal RNA processing in the nucleolus and the apum 23 mutant showed a developmental defeat phenotype [37]. It is possible that APUM24 could function in the ribosomal RNA processing because APUM24 predominantly localizes to the nucleolus [49]. APUM5 and APUM6 were highly abundant at developmental stages (Figure 3). However, these mutants did not show abnormal developmental phenotypes. APUM1 to APUM6 have a similar protein structure and might have the same redundancy. In the future, this will be studied for genetic crossover with APUM1 to APUM6 mutants. In rice, at least four rice Pum genes are highly expressed at the vegetative stage (Figure 2B). Plant Pum proteins could play a role in development and differentiation. 
A
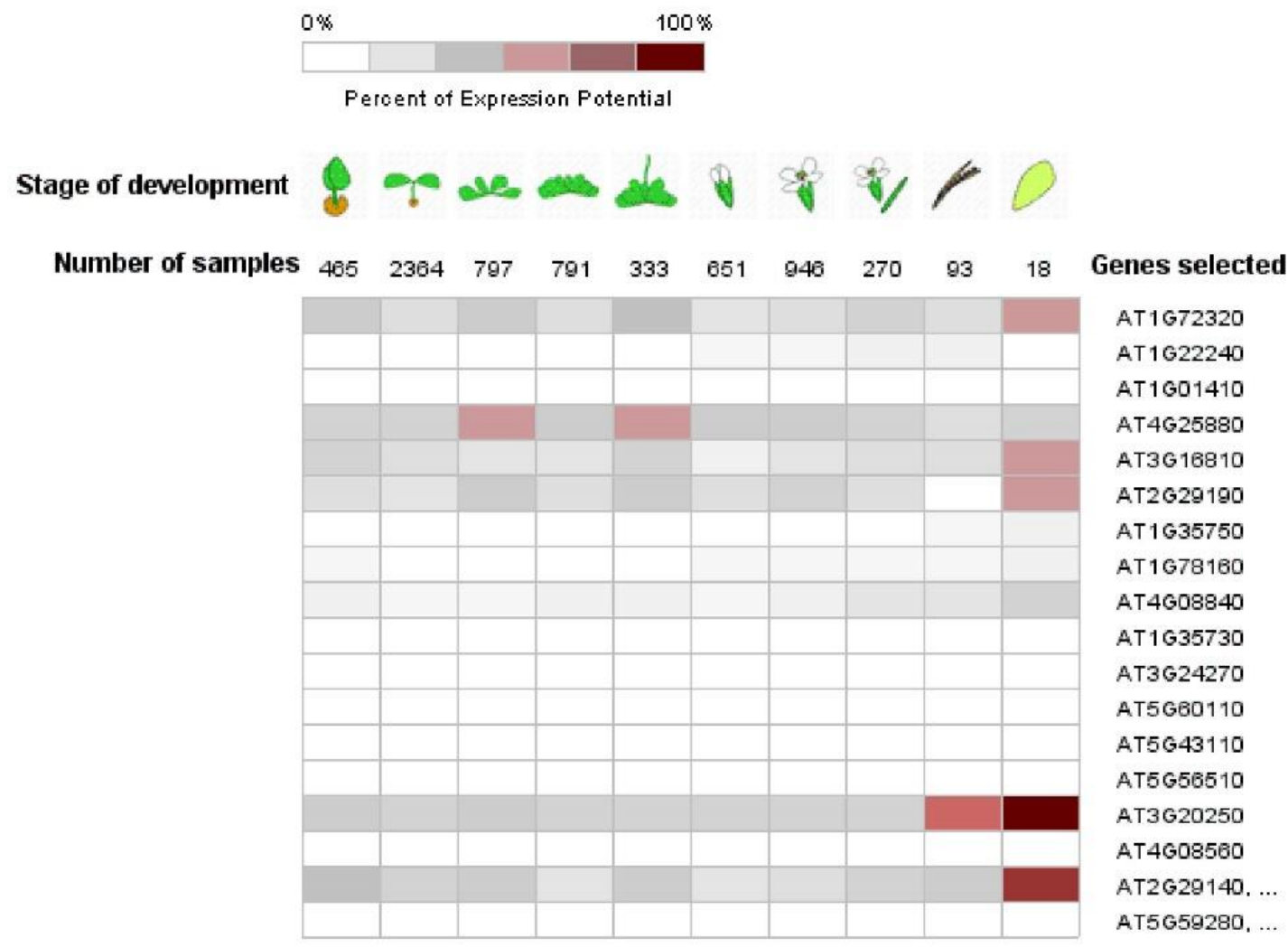

B
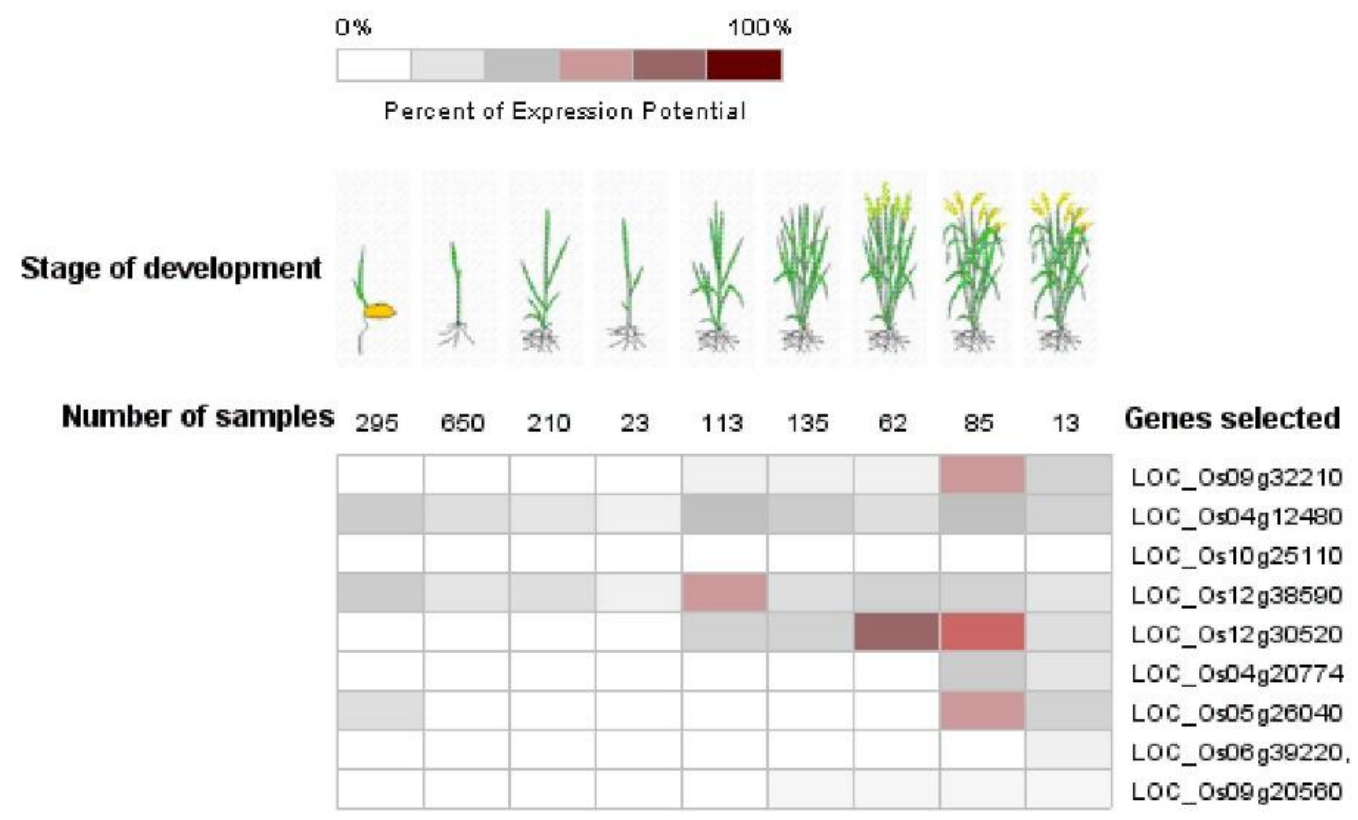

Figure 2. Expression pattern of Arabidopsis and rice Pum in development. (A,B) Expression pattern of Arabidopsis and rice Pum was analyzed at developmental stage using the Genevestigator (https:/ / www.genevestigator.com accessed on 13 November 2021). Expression levels of Arabidopsis and rice Pum vary under developmental stages. Transcript levels were assessed using microarray data available from Genevestigator. 
A

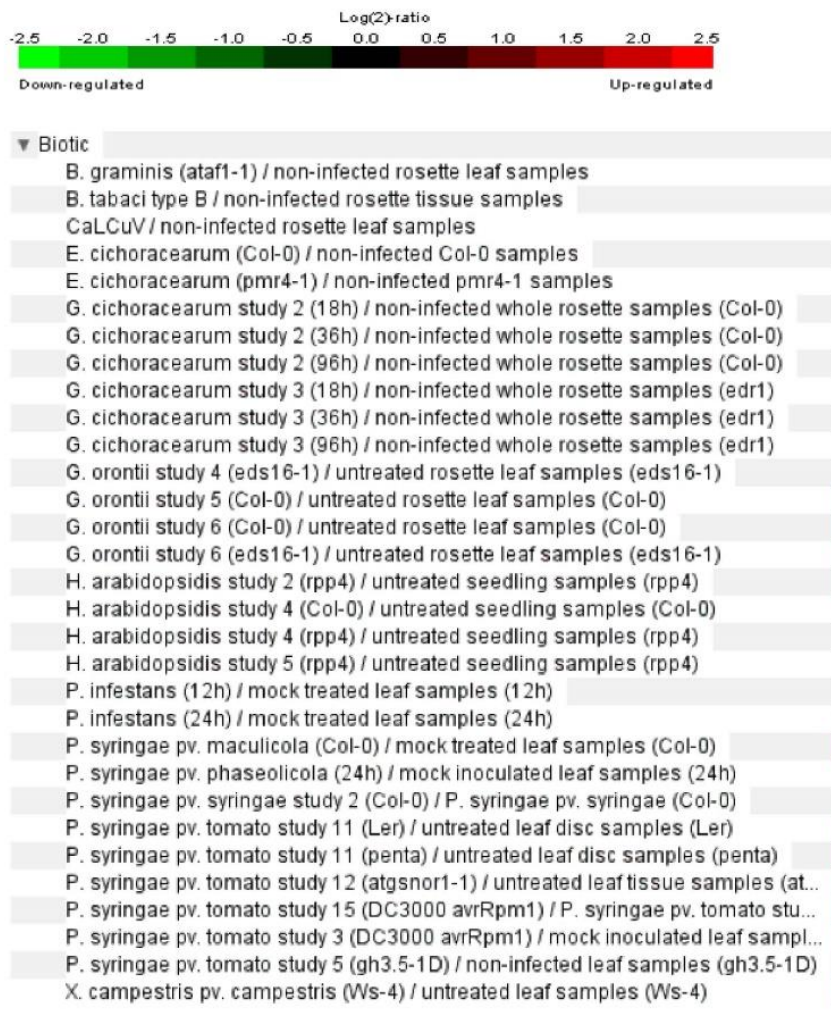
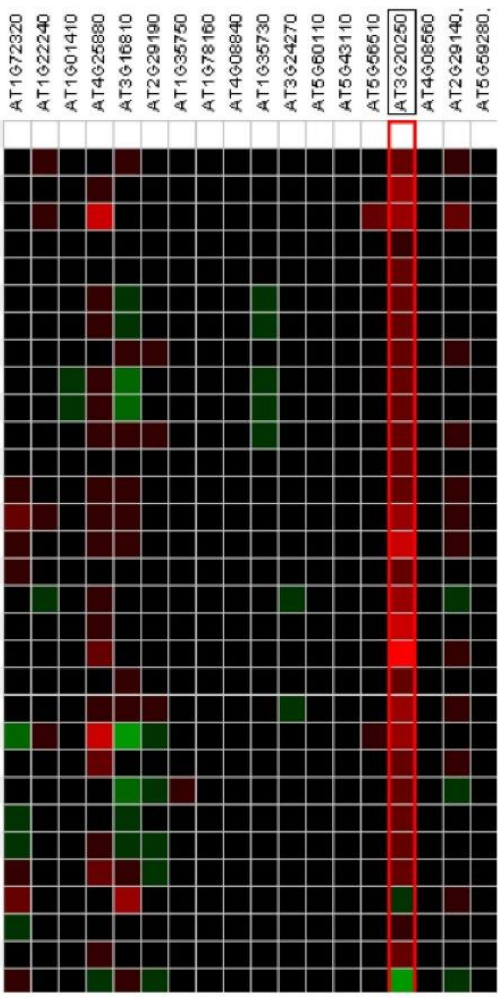

B

\begin{tabular}{|c|}
\hline $5 \quad \begin{array}{c}\log (2) \text { ratio } \\
0.0\end{array} 0.5$ \\
\hline un-regulated \\
\hline$\checkmark$ Biotic \\
\hline A. tumefaciens ( $6 \mathrm{~h}$ ) / untreated calli samples \\
\hline A. tumefaciens study 2 (Zhenshan 97) / untreated calli samples (Zhenshan 97) \\
\hline M. graminicola (4dpi) / untreated root samples \\
\hline M. grisea (3dpi) / mock treated leaf samples (3dpi) \\
\hline M. incognita (6dpi) / uninfected root samples \\
\hline M. orzzae (2dpi) / mock treated root samples (2dpi) \\
\hline M. oryzae (4dpi) / mock treated root samples (4dpi) \\
\hline M. oryzae (6dpi) / mock treated root samples (6dpi) \\
\hline N. Iugens study 2 (Taichung Native-1) / untreated stem samples (Taichung Nati. \\
\hline S. hermonthica study 3 (IAC 165) / mock treated root samples (IAC 165) \\
\hline X. oryzae pv. oryzae (2hpi) / mock treated shoot samples (2hpi) \\
\hline X. onzzae pv. oryzae PX086 (IR24) / mock treated leaf samples (IR24) \\
\hline X. oryzae pv. oryzae PX086 (Nipponbare) / mock treated leaf samples (Nipponb.. \\
\hline X. oryzae pv. oryzae PX086 (Nipponbare) /X. oryzae pv. oryzae T7174 (Nipponba. \\
\hline X. oryzae pv. oryzae PX099A (IR24) / mock treated leaf samples (IR24) \\
\hline X. oryzae pv. oryzae PX099A study 2 (Nipponbare) / mock treated leaf samples (. \\
\hline X. oryzae pv. oryzae PXO99AME1 (Nipponbare) / mock treated leaf samples (Nip. \\
\hline X. oryzae pv. oryzae study 4 (IR24) /X. oryzae pv. oryzae study 2 (IR24) \\
\hline X. oryzae pv. oryzae study 4 (IRBB5) /X. oryzae pv. oryzae study 2 (IRBB5) \\
\hline X. oryzae pv. orzzae study 4 (IRBB7) /X. oryzae pv. oryzae study 2 (IRBB7) \\
\hline X. oryzae pv. oryzae study 5 (IR24) / X. oryzae pv. oryzae study 2 (IR 24$)$ \\
\hline X. oryzae pv. oryzae study 5 (IRBB5) / X. oryzae pv. oryzae study 2 (IRBB5) \\
\hline X. oryzae pv. oryzae study 5 (IRBB7) /X. oryzae pv. oryzae study 2 (IRBB7) \\
\hline X. oryzae pv. oryzae T7174 (IR24) / mock treated leaf samples (IR24) \\
\hline X. oryzae pv. oryzicola (2hpi) / X. oryzae pv. oryzae (2hpi) \\
\hline X. oryzae pv. oryzicola study 2 (9804-Rxo1) / untreated fla \\
\hline oryzae pv. oryzicola study 3 (IR24) / mock treated leaf samples ( \\
\hline
\end{tabular}
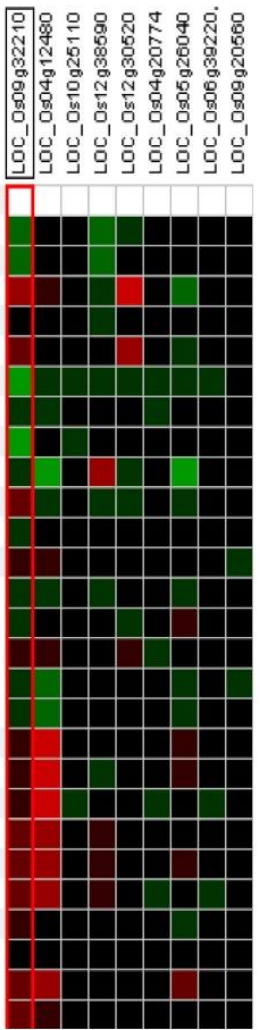

Figure 3. Biotic stress response of Arabidopsis and rice Pum. (A,B) Expression pattern of Arabidopsis and rice Pum is analyzed in biotic stress response using the Genevestigator. Arabidopsis and rice Pum transcript levels were assessed using microarray data available from Genevestigator. Expressions patterns were searched in a range of biotic stress conditions in this database. Red colors indicate genes that were upregulated relative to the control for a given treatment, and green colors indicate genes that were downregulated relative to the control. 


\section{Plant Pum Function in Biotic Stress}

In Arabidopsis, some putative target RNAs of Pum were identified by yeast in a three-hybrid system. These genes contained Pumilio RNA binding motifs at the $3^{\prime}$ UTR regions [34]. For example, Responsive to dehydration 19 (RD19) and Plant homeodomain (PHD) containing protein (At3g63500) were isolated [34]. RD19 encodes cysteine protease and is involved in resistance and gene-mediated immunity via interaction with Ralstonia solanacearum type III effector PopP2 [56]. This means that plant Pum could be related to plant immunity. APUM5 is involved in plant defense against CMV infection and function as a translational repressor via binding to the $3^{\prime}$ UTR of CMV [32]. Furthermore, gene expression analysis of Arabidopsis Pum family exhibits enhanced or repressed expression levels upon the Cabbage leaf curl virus (CaLCuV), Golovinomyces cichoracearum, Hyaloperonospora arabidopsidis, Peudomonas syringae and Xanthomonas campestris (Figure 3A). Similarly, rice Pum genes are upregulated or downregulated by Mycosphaerella graminicola, Meloidogyne incognita, Magnaporthe oryzae, Nilaparvata lugens and Xanthomonas oryzae infections (Figure 3B). When infected with M. oryzae, most of the rice Pum genes were shown to be repressed. Expression levels of OS09g32210 and OS04g12480 genes were highly enhanced upon X. oryzae infection in IRBB5/7 (resistance) and IR24 (susceptible) rice plants (Figure 3B). Thus, infectious pathogens may affect plant Pum gene expression and attenuate plant immunity. In D. melanogaster Pum mutants, some antibacterial genes are highly expressed [19]. In particular, CG18372 (Attactin-B), CG4740 (Attactin-C), CG7629 (Attactin-D), CG1373 (Cecropin C) and CG13422 (Gram-negative binding protein) were encoded antibacterial peptides [19]. The immunity function of Pum in plant and mammalian genes will be important to investigate in the extended study of transcriptional/translational control.

\section{Plant Pum Function in Abiotic Stress}

Phytohormone abscisic acid (ABA) and brassinosteroid (BR) have essential roles in the manipulation of abiotic stress responses [57,58]. Expression patterns of Arabidopsis Pum are dynamically changed by ABA and BR treatment (Figure 4A). Recently, the apum 23 mutant exhibited altered gene expression patterns of ABA and salt-stress-responsive genes. APUM23 is essential for salt sensitivity in response salt stress [59]. APUM5 has also been reported to be involved in salt tolerance [60]. The overexpression of APUM9 results in enhanced heat stress tolerance [61]. Furthermore, the expression of several Arabidopsis Pum genes is changed by environment stresses such as cold, drought and salt stresses (Figure 4A). Rice Pum genes responded to auxin and cytokinin but not ABA (Figure 4B). Basically, cytokinin and auxin are also deeply associated with abiotic stress responses [62,63]. Plant Pum can influence the target RNA through environmental stresses and phytohormone molecules. 
A

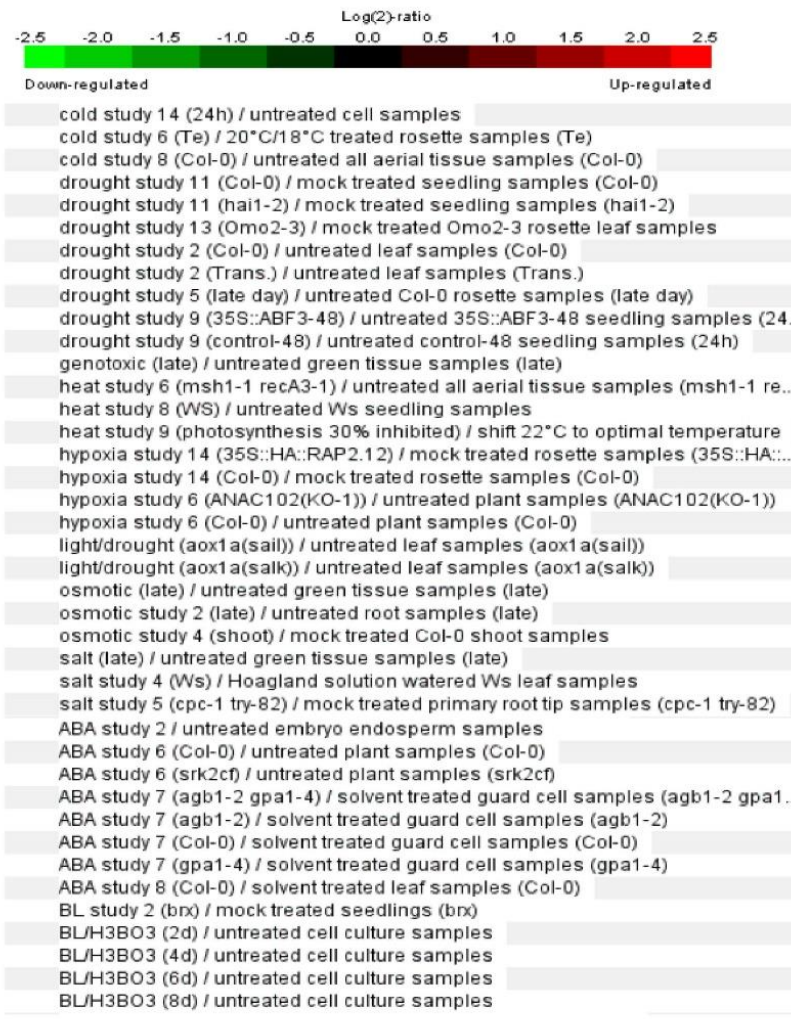

B

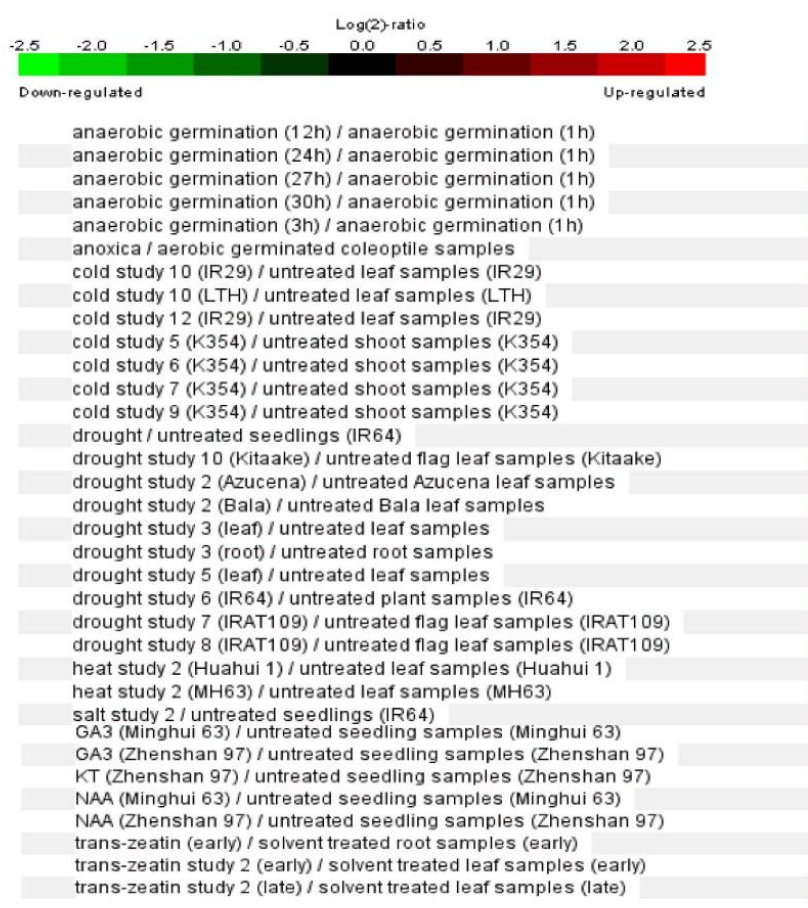

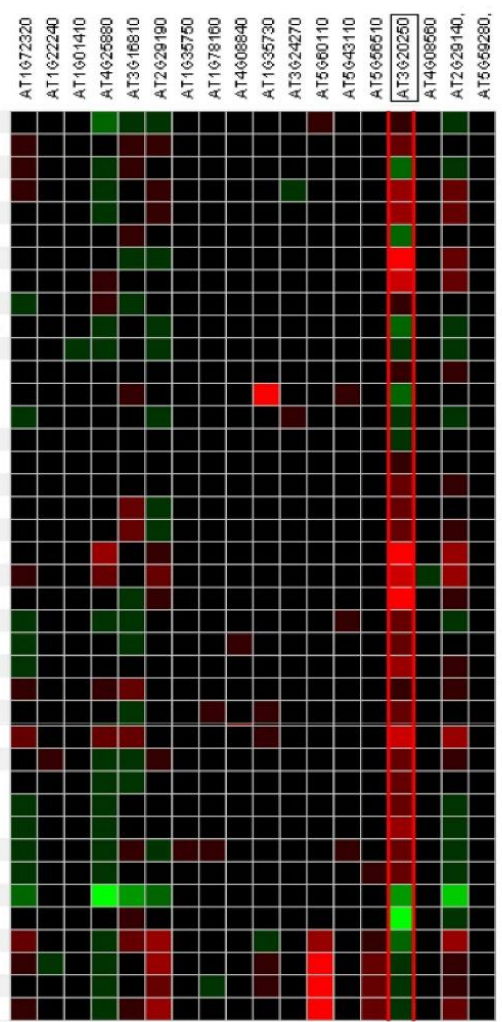

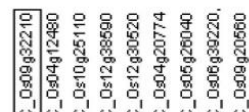

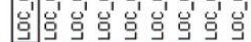

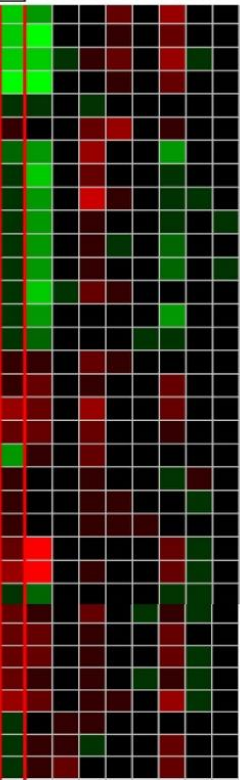

Figure 4. Differential expression patterns of Pum genes in Arabidopsis and rice in response to abiotic stresses or phytohormones. (A) Expression pattern of Arabidopsis Pum was analyzed in abiotic stresses (cold, drought, heat, hypoxia, osmotic and salt) and phytohormones (ABA and brassinosteroid) treatments using Genevestigator. (B) Expression pattern of rice Pum was analyzed in abiotic stresses (anaerobic, cold, drought, heat, and salt) and phytohormones (gibberellin, auxin, and cytokinin) treatments using Genevestigator. Arabidopsis and rice Pum transcript levels were assessed using microarray data available from Genevestigator. Expressions patterns were searched in a range of abiotic stress conditions in this database. Red colors indicate genes that were upregulated relative to the control for a given treatment, and green colors indicate genes that were downregulated relative to the control. 


\section{The Multifunctional Plant Pum Protein and Crop Engineering}

The translational control of gene expression is an important step for the survival of plants. Pum proteins evolutionally conserve the canonical Pum-HD RNA binding domain in most of the eukaryotes. This Pum-HD confers target RNA specificity via direct binding and functions as a protein-protein interaction platform. Sometimes, Pum acts as a translational activator. Until now, plant Pum functions were not well known. The plant Pum family contains the highest number of members, about twenty, compared with the mammalian Pum family. This implies that many plant Pum proteins might have plantspecific functions and could have plant-specific targets. From the in silico data analysis, it is shown that plant Pums could be associated with a variety of signaling pathways. This regulation could be more complicated because plant hormones exhibit crosstalk between different plant hormones. A better understanding of the plant Pum regulation mechanism would help innovate new strategies to improve crop plant engineering. Thus, it would be interesting to identify the putative RNA targets and generate customized Pum-HD proteins for agriculture.

Funding: This work was supported by research funds of Kunsan National University.

Institutional Review Board Statement: Not applicable.

Informed Consent Statement: Not applicable.

Data Availability Statement: Not applicable.

Conflicts of Interest: The authors declare no conflict of interest.

\section{References}

1. Lee, M.H.; Wu, X.; Zhu, Y. RNA-binding protein PUM2 regulates mesenchymal stem cell fate via repression of JAK2 and RUNX2 mRNAs. J. Cell Physiol. 2020, 235, 3874-3885. [CrossRef] [PubMed]

2. Yang, H.; Deng, Z.; Pan, X.; Shen, H.B.; Choi, K.S.; Wang, L.; Wang, S.; Wu, J. RNA-binding protein recognition based on multi-view deep feature and multi-label learning. Brief. Bioinform. 2020, 22, bbaa174. [CrossRef] [PubMed]

3. Goldstrohm, A.C.; Hall, T.M.T.; McKenney, K.M. Post-transcriptional Regulatory Functions of Mammalian Pumilio Proteins. Trends Genet. 2018, 34, 972-990. [CrossRef] [PubMed]

4. Nishanth, M.J.; Simon, B. Functions, mechanisms and regulation of Pumilio/Puf family RNA binding proteins: A comprehensive review. Mol. Biol. Rep. 2020, 47, 785-807. [CrossRef] [PubMed]

5. Jia, J.; Yao, P.; Arif, A.; Fox, P.L. Regulation and dysregulation of 3’UTR-mediated translational control. Curr. Opin. Genet. Dev. 2013, 23, 29-34. [CrossRef] [PubMed]

6. Qiu, C.; Dutcher, R.C.; Porter, D.F.; Arava, Y.; Wickens, M.; Hall, T.M.T. Distinct RNA-binding modules in a single PUF protein cooperate to determine RNA specificity. Nucleic Acids Res. 2019, 47, 8770-8784. [CrossRef] [PubMed]

7. Miao, J.; Fan, Q.; Parker, D.; Li, X.; Li, J.; Cui, L. Puf mediates translation repression of transmission-blocking vaccine candidates in malaria parasites. PLoS Pathog. 2013, 9, e1003268. [CrossRef] [PubMed]

8. Yan, Y.; Ham, B.-K.; Chong, Y.H.; Yeh, S.-D.; Lucas, W.J. A Plant SMALL RNA-BINDING PROTEIN 1 Family Mediates Cell-to-Cell Trafficking of RNAi Signals. Mol. Plant 2020, 13, 321-335. [CrossRef]

9. Galgano, A.; Forrer, M.; Jaskiewicz, L.; Kanitz, A.; Zavolan, M.; Gerber, A.P. Comparative analysis of mRNA targets for human PUF-family proteins suggests extensive interaction with the miRNA regulatory system. PLoS ONE 2008, 3, e3164. [CrossRef]

10. Joshna, C.R.; Saha, P.; Atugala, D.; Chua, G.; Muench, D.G. Plant PUF RNA-binding proteins: A wealth of diversity for post-transcriptional gene regulation. Plant Sci. 2020, 297, 110505. [CrossRef] [PubMed]

11. Spassov, D.S.; Jurecic, R. The PUF family of RNA-binding proteins: Does evolutionarily conserved structure equal conserved function? IUBMB Life 2003, 55, 359-366. [CrossRef]

12. Spassov, D.S.; Jurecic, R. Cloning and comparative sequence analysis of PUM1 and PUM2 genes, human members of the Pumilio family of RNA-binding proteins. Gene 2002, 299, 195-204. [CrossRef]

13. Spassov, D.S.; Jurecic, R. Mouse Pum1 and Pum2 genes, members of the Pumilio family of RNA-binding proteins, show differential expression in fetal and adult hematopoietic stem cells and progenitors. Blood Cells Mol. Dis. 2003, 30, 55-69. [CrossRef]

14. Gerber, A.P.; Herschlag, D.; Brown, P.O. Extensive association of functionally and cytotopically related mRNAs with Puf family RNA-binding proteins in yeast. PLoS Biol. 2004, 2, E79. [CrossRef]

15. Stumpf, C.R.; Kimble, J.; Wickens, M. A Caenorhabditis elegans PUF protein family with distinct RNA binding specificity. RNA 2008, 14, 1550-1557. [CrossRef]

16. Caro, F.; Bercovich, N.; Atorrasagasti, C.; Levin, M.J.; Vazquez, M.P. Trypanosoma cruzi: Analysis of the complete PUF RNA-binding protein family. Exp. Parasitol. 2006, 113, 112-124. [CrossRef] [PubMed] 
17. Cui, L.; Fan, Q.; Li, J. The malaria parasite Plasmodium falciparum encodes members of the Puf RNA-binding protein family with conserved RNA binding activity. Nucleic Acids Res. 2002, 30, 4607-4617. [CrossRef] [PubMed]

18. Schweers, B.A.; Walters, K.J.; Stern, M. The Drosophila melanogaster translational repressor pumilio regulates neuronal excitability. Genetics 2002, 161, 1177-1185. [CrossRef] [PubMed]

19. Gerber, A.P.; Luschnig, S.; Krasnow, M.A.; Brown, P.O.; Herschlag, D. Genome-wide identification of mRNAs associated with the translational regulator PUMILIO in Drosophila melanogaster. Proc. Natl. Acad. Sci. USA 2006, 103, 4487-4492. [CrossRef] [PubMed]

20. Van Bel, M.; Proost, S.; Wischnitzki, E.; Movahedi, S.; Scheerlinck, C.; Van de Peer, Y.; Vandepoele, K. Dissecting plant genomes with the PLAZA comparative genomics platform. Plant Physiol. 2012, 158, 590-600. [CrossRef] [PubMed]

21. Letunic, I.; Doerks, T.; Bork, P. SMART 7: Recent updates to the protein domain annotation resource. Nucleic Acids Res. 2012, 40, D302-D305. [CrossRef]

22. Wang, X.; McLachlan, J.; Zamore, P.D.; Hall, T.M. Modular recognition of RNA by a human pumilio-homology domain. Cell 2002, 110, 501-512. [CrossRef]

23. Wharton, R.P.; Sonoda, J.; Lee, T.; Patterson, M.; Murata, Y. The Pumilio RNA-binding domain is also a translational regulator. Mol. Cell 1998, 1, 863-872. [CrossRef]

24. Najdrova, V.; Stairs, C.W.; Vinopalova, M.; Voleman, L.; Dolezal, P. The evolution of the Puf superfamily of proteins across the tree of eukaryotes. BMC Biol. 2020, 18, 77. [CrossRef] [PubMed]

25. Miller, M.T.; Higgin, J.J.; Hall, T.M. Basis of altered RNA-binding specificity by PUF proteins revealed by crystal structures of yeast Puf4p. Nat. Struct. Mol. Biol. 2008, 15, 397-402. [CrossRef]

26. Ryder, S.P. Pumilio RNA recognition: The consequence of promiscuity. Structure 2011, 19, 277-279. [CrossRef]

27. Cooke, A.; Prigge, A.; Opperman, L.; Wickens, M. Targeted translational regulation using the PUF protein family scaffold. Proc. Natl. Acad. Sci. USA 2011, 108, 15870-15875. [CrossRef] [PubMed]

28. Cheong, C.G.; Hall, T.M. Engineering RNA sequence specificity of Pumilio repeats. Proc. Natl. Acad. Sci. USA 2006, 103, 13635-13639. [CrossRef] [PubMed]

29. Choudhury, R.; Tsai, Y.S.; Dominguez, D.; Wang, Y.; Wang, Z. Engineering RNA endonucleases with customized sequence specificities. Nat. Commun. 2012, 3, 1147. [CrossRef] [PubMed]

30. Wang, Y.; Wang, Z.; Hall, T.M. Engineered proteins with PUF scaffold to manipulate RNA metabolism. FEBS J. 2013, 280, 3755-3767. [CrossRef] [PubMed]

31. Saint-Georges, Y.; Garcia, M.; Delaveau, T.; Jourdren, L.; Le Crom, S.; Lemoine, S.; Tanty, V.; Devaux, F.; Jacq, C. Yeast mitochondrial biogenesis: A role for the PUF RNA-binding protein Puf3p in mRNA localization. PLoS ONE 2008, 3, e2293. [CrossRef] [PubMed]

32. Huh, S.U.; Kim, M.J.; Paek, K.H. Arabidopsis Pumilio protein APUM5 suppresses Cucumber mosaic virus infection via direct binding of viral RNAs. Proc. Natl. Acad. Sci. USA 2013, 110, 779-784. [CrossRef]

33. Sonoda, J.; Wharton, R.P. Recruitment of Nanos to hunchback mRNA by Pumilio. Genes Dev. 1999, 13, 2704-2712. [CrossRef] [PubMed]

34. Francischini, C.W.; Quaggio, R.B. Molecular characterization of Arabidopsis thaliana PUF proteins-binding specificity and target candidates. FEBS J. 2009, 276, 5456-5470. [CrossRef] [PubMed]

35. Haramati, O.; Brodov, A.; Yelin, I.; Atir-Lande, A.; Samra, N.; Arava, Y. Identification and characterization of roles for Puf1 and Puf2 proteins in the yeast response to high calcium. Sci. Rep. 2017, 7, 3037. [CrossRef]

36. Gu, W.; Deng, Y.; Zenklusen, D.; Singer, R.H. A new yeast PUF family protein, Puf6p, represses ASH1 mRNA translation and is required for its localization. Genes Dev. 2004, 18, 1452-1465. [CrossRef]

37. Abbasi, N.; Kim, H.-B.; Park, N.-I.; Kim, H.-S.; Kim, Y.-K.; Park, Y.-I.; Choi, S.-B. APUM23, a nucleolar Puf domain protein, is involved in pre-ribosomal RNA processing and normal growth patterning in Arabidopsis. Plant J. 2010, 64, 960-976. [CrossRef] [PubMed]

38. Kang, H.S.; Beak, J.Y.; Kim, Y.S.; Petrovich, R.M.; Collins, J.B.; Grissom, S.F.; Jetten, A.M. NABP1, a novel RORgamma-regulated gene encoding a single-stranded nucleic-acid-binding protein. Biochem. J. 2006, 397, 89-99. [CrossRef] [PubMed]

39. Lorkovic, Z.J.; Barta, A. Genome analysis: RNA recognition motif (RRM) and K homology (KH) domain RNA-binding proteins from the flowering plant Arabidopsis thaliana. Nucleic Acids Res. 2002, 30, 623-635. [CrossRef] [PubMed]

40. Huh, S.U.; Paek, K.H. Role of Arabidopsis Pumilio RNA binding protein 5 in virus infection. Plant Signal. Behav. 2013, 8, e23975. [CrossRef]

41. Wu, J.; Campbell, Z.T.; Menichelli, E.; Wickens, M.; Williamson, J.R. A protein.protein interaction platform involved in recruitment of GLD-3 to the FBF.fem-3 mRNA complex. J. Mol. Biol. 2013, 425, 738-754. [CrossRef] [PubMed]

42. Goldstrohm, A.C.; Hook, B.A.; Seay, D.J.; Wickens, M. PUF proteins bind Pop2p to regulate messenger RNAs. Nat. Struct. Mol. Biol. 2006, 13, 533-539. [CrossRef]

43. Van Etten, J.; Schagat, T.L.; Hrit, J.; Weidmann, C.A.; Brumbaugh, J.; Coon, J.J.; Goldstrohm, A.C. Human Pumilio proteins recruit multiple deadenylases to efficiently repress messenger RNAs. J. Biol. Chem. 2012, 287, 36370-36383. [CrossRef] [PubMed]

44. Goldstrohm, A.C.; Seay, D.J.; Hook, B.A.; Wickens, M. PUF protein-mediated deadenylation is catalyzed by Ccr4p. J. Biol. Chem. 2007, 282, 109-114. [CrossRef] 
45. Arae, T.; Morita, K.; Imahori, R.; Suzuki, Y.; Yasuda, S.; Sato, T.; Yamaguchi, J.; Chiba, Y. Identification of Arabidopsis CCR4-NOT Complexes with Pumilio RNA-Binding Proteins, APUM5 and APUM2. Plant Cell Physiol. 2019, 60, 2015-2025. [CrossRef] [PubMed]

46. Traven, A.; Lo, T.L.; Lithgow, T.; Heierhorst, J. The yeast PUF protein Puf5 has Pop2-independent roles in response to DNA replication stress. PLOS ONE 2010, 5, e10651. [CrossRef]

47. Friend, K.; Campbell, Z.T.; Cooke, A.; Kroll-Conner, P.; Wickens, M.P.; Kimble, J. A conserved PUF-Ago-eEF1A complex attenuates translation elongation. Nat. Struct. Mol. Biol. 2012, 19, 176-183. [CrossRef]

48. Tam, P.P.; Barrette-Ng, I.H.; Simon, D.M.; Tam, M.W.; Ang, A.L.; Muench, D.G. The Puf family of RNA-binding proteins in plants: Phylogeny, structural modeling, activity and subcellular localization. BMC Plant Biol. 2010, 10, 44. [CrossRef]

49. Park, S.H.; Kim, H.-S.; Kalita, P.J.; Choi, S.-B. Structural and functional similarities and differences in nucleolar Pumilio RNAbinding proteins between Arabidopsis and the charophyte Chara corallina. BMC Plant Biol. 2020, 20, 230. [CrossRef]

50. Wreden, C.; Verrotti, A.C.; Schisa, J.A.; Lieberfarb, M.E.; Strickland, S. Nanos and pumilio establish embryonic polarity in Drosophila by promoting posterior deadenylation of hunchback mRNA. Development 1997, 124, 3015-3023. [CrossRef] [PubMed]

51. Bouchabke-Coussa, O.; Obellianne, M.; Linderme, D.; Montes, E.; Maia-Grondard, A.; Vilaine, F.; Pannetier, C. Wuschel overexpression promotes somatic embryogenesis and induces organogenesis in cotton (Gossypium hirsutum L.) tissues cultured in vitro. Plant Cell Rep. 2013, 32, 675-686. [CrossRef] [PubMed]

52. Williams, E.L.; De Smet, I. Development: CLAVATA1 joins the club of root stem cell regulators. Curr. Biol. 2013, 23, R245-R247. [CrossRef]

53. Moore, F.L.; Jaruzelska, J.; Fox, M.S.; Urano, J.; Firpo, M.T.; Turek, P.J.; Dorfman, D.M.; Pera, R.A.R. Human Pumilio-2 is expressed in embryonic stem cells and germ cells and interacts with DAZ (Deleted in AZoospermia) and DAZ-like proteins. Proc. Natl. Acad. Sci. USA 2003, 100, 538-543. [CrossRef] [PubMed]

54. Lin, K.; Qiang, W.; Zhu, M.; Ding, Y.; Shi, Q.; Chen, X.; Zsiros, E.; Wang, K.; Yang, X.; Kurita, T.; et al. Mammalian Pum1 and Pum2 Control Body Size via Translational Regulation of the Cell Cycle Inhibitor Cdkn1b. Cell Rep. 2019, 26, 2434-2450.e6. [CrossRef]

55. Racher, H.; Hansen, D. PUF-8, a Pumilio homolog, inhibits the proliferative fate in the Caenorhabditis elegans germline. G3 Genes Genomes Genet. 2012, 2, 1197-1205. [CrossRef] [PubMed]

56. Bernoux, M.; Timmers, T.; Jauneau, A.; Briere, C.; de Wit, P.J.; Marco, Y.; Deslandes, L. RD19, an Arabidopsis cysteine protease required for RRS1-R-mediated resistance, is relocalized to the nucleus by the Ralstonia solanacearum PopP2 effector. Plant Cell 2008, 20, 2252-2264. [CrossRef] [PubMed]

57. Tuteja, N. Abscisic Acid and abiotic stress signaling. Plant Signal. Behav. 2007, 2, 135-138. [CrossRef]

58. Bajguz, A.; Hayat, S. Effects of brassinosteroids on the plant responses to environmental stresses. Plant Physiol. Biochem. 2009, 47, 1-8. [CrossRef] [PubMed]

59. Huang, K.-C.; Lin, W.-C.; Cheng, W.-H. Salt hypersensitive mutant 9, a nucleolar APUM23 protein, is essential for salt sensitivity in association with the ABA signaling pathway in Arabidopsis. BMC Plant Biol. 2018, 18, 40. [CrossRef]

60. Huh, S.U.; Paek, K.H. APUM5, encoding a Pumilio RNA binding protein, negatively regulates abiotic stress responsive gene expression. BMC Plant Biol. 2014, 14, 75. [CrossRef]

61. Nyiko, T.; Auber, A.; Bucher, E. Functional and molecular characterization of the conserved Arabidopsis PUMILIO protein, APUM9. Plant Mol. Biol. 2019, 100, 199-214. [CrossRef] [PubMed]

62. Xu, J.; Li, X.-L.; Luo, L. Effects of engineered Sinorhizobium meliloti on cytokinin synthesis and tolerance of alfalfa to extreme drought stress. Appl. Environ. Microbiol. 2012, 78, 8056-8061. [CrossRef] [PubMed]

63. Popko, J.; Hansch, R.; Mendel, R.-R.; Polle, A.; Teichmann, T. The role of abscisic acid and auxin in the response of poplar to abiotic stress. Plant Biol. 2010, 12, 242-258. [CrossRef] [PubMed] 